\title{
ANALYSIS OF FATIGUE CRACK LENGTH DURING THE DETERMINATION OF FRACTURE TOUGHNESS OF THE LAYER MATERIAL AL-TI
}

\author{
M. Kotyk* , P. Maćkowiak ${ }^{* *}$, D. Placzek ${ }^{* * *}$, R. Sołtysiak ${ }^{\dagger}$
}

\begin{abstract}
The article presents the results of analysis of the breakthrough of CT type compact samples. The samples were loaded to determine typical values for determining the fracture toughness. The tested material was an explosively bonded composite formed from the combination of Ti6Al4V titanium alloy and AA2519 aluminum alloy. The paper also presents the author's system allowing for the automation of the process of generating the initial fatigue crack. As a result of the tests, it was determined that the crack in the base materials of the composite is not equal.
\end{abstract}

Keywords: fracture mechanics, $J$ integral, crack length, crack tip opening displacement, stress intensity factor

\section{Introduction}

Layered material AA2519 - AA1050 - Ti6A14V is a completely new construction material, which was created as a result of commercial cooperation between Explomet and research centers located throughout the country. These included scientific units such as Warsaw University of Technology, Military University of Technology in Warsaw, University of Technology and Life Sciences in Bydgoszcz, Space research Centre, Institute of Non-Ferrous Metals in Gliwice and Polish Academy of Sciences. The company is an experienced producer of layered materials combined with high energy methods in various configurations and different number of layers. According to the technology developed by the producer, the joining was carried out by parallel cladding of the AA2519 aluminum layer and the Ti6A14V titanium layer, the light alloy being the applied layer. As a result, the titanium layer did not have direct contact with the explosion. Deformations created during the detonation of the load did not allow for the exact determination of the thickness of individual layers in composite. It can be assumed, however, that they were about $5 \mathrm{~mm}$ long. Before the bonding process, a $0.20 \mathrm{~mm}$ AA1050 alloy layer was rolled up. The welding process was carried that the velocity of propagation of the flame front during detonation was in the range from $1850 \mathrm{~m} / \mathrm{s}$ to $2000 \mathrm{~m} / \mathrm{s}$, with an attack angle of $15^{\circ}$.

The effect of the described processes is to achieve a connection speed of 420-620 mm / s, and the creation of a geometrically complicated structure in the connecting layer, which was discussed in detail in the paper (Bazarnik and all, 2016).

The composite sheet after the explosive welding is presented in Figure 1, while the microstructure of the joint with the highlighted layers is shown in Figure 2.

mgr inż. Maciej Kotyk, Wydział Inżynierii Mechanicznej, Uniwersytet Technologiczno-Przyrodniczy w Bydgoszczy, al. Prof. S. Kaliskiego 7, 85-796 Bydgoszcz,PL, maciej.kotyk@utp.edu.pl

** mgr inż. Paweł Maćkowiak, Wydział Inżynierii Mechanicznej, Uniwersytet Technologiczno-Przyrodniczy w Bydgoszczy, al. Prof. S. Kaliskiego 7, 85-796 Bydgoszcz,PL, pawel.mackowiak@utp.edu.pl

*** Dominika Płaczek, Wydział Inżynierii Mechanicznej, Uniwersytet Technologiczno-Przyrodniczy w Bydgoszczy, al. Prof. S. Kaliskiego 7, 85-796 Bydgoszcz,PL

$\dagger$ Robert Sołtysiak, Wydział Inżynierii Mechanicznej, Uniwersytet Technologiczno-Przyrodniczy w Bydgoszczy, al. Prof. S. Kaliskiego 7, 85-796 Bydgoszcz,PL, robert.soltysiak@utp.edu.pl 


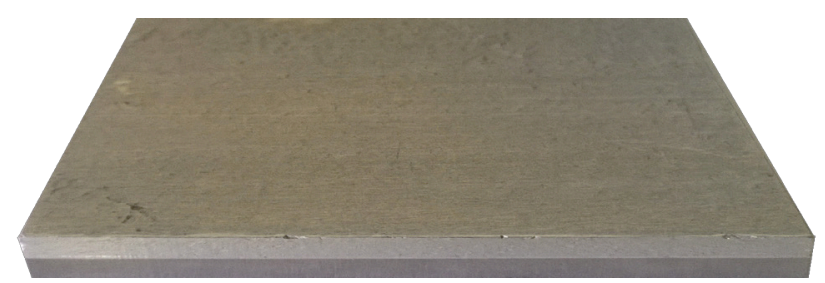

Fig. 1: Al - Ti composite after explosive welding

a)

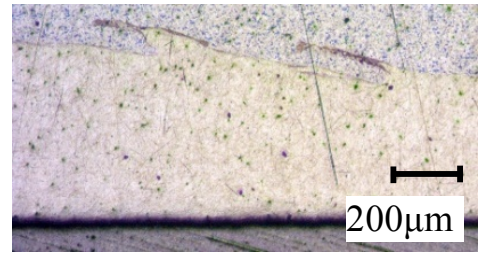

b)

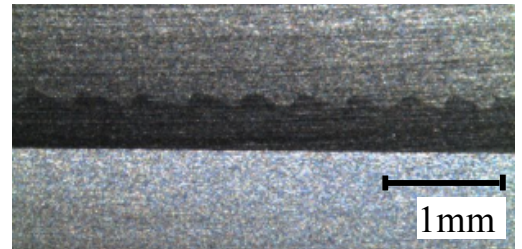

Fig. 2: a) Connection zone, b) connector structure

In the illustration you can successfully distinguish both materials included in the composite and the characteristic, irregular transition zone between materials. It contains intermetallic phases $\mathrm{Al}_{3} \mathrm{Ti}$ or $\mathrm{Ti}_{3} \mathrm{Al}$.

Composite $\mathrm{Al}-\mathrm{Ti}$ is a completely new and does not yet have a strictly defined application. Dedicated facilities for which the material was designed, are the application of air and space. Such constructions are subject to high risk and security is a priority (Melski, 2016). As a result, it is necessary to make a research involving the full identification of this material. There are not many articles of this composite in the literature so far.

Unfortunately, none of the found papers concerns determination of a crack resistance of the described. To determine experimentally the fracture toughness of this material it is necessary to measure the length of fatigue cracks every time. The method for measuring the length of fatigue crack in a laminar material is presented in Chapter 2.

\section{Methods}

When you generate the initial fatigue crack, to observe the phenomena that took place on the surface of the test material, digital cameras were placed on both sides of the test object. Digital cameras have been placed in such a way that on recorded image was visible mechanical notch and propagating crack. Equipment to observe cracks in the sample shown in Figure 3.

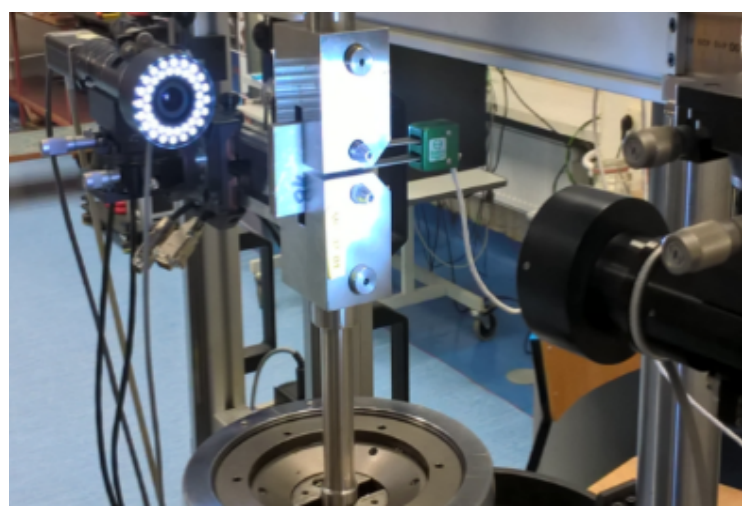

Fig. 3: Optical system which allows for observation and later analysis increment cracks in the samples when fracture toughness is determined

The purpose of observation, analysis and control of the crack growth in compact specimen, as well as machine control, written and configured a computer program whose window graphic is presented in Figure 4. An essential software was stopping the generation of fatigue fissure in time, when the length of the initial fatigue crack reaches a previously set length. The software worked on a digital image correlation when comparing photos with each other. Thanks to that detected position of top of the crack. The loading machine stops when the line drawn by the program overlaps with the one marked by the user. Featured process in graphical form is presented in Figure 5. 


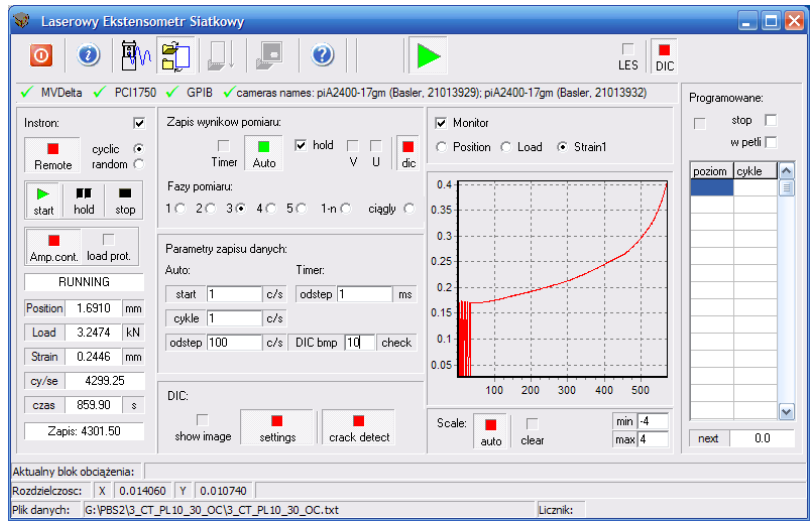

Fig. 4: Graphic window of the author's program for controlling the testing machine
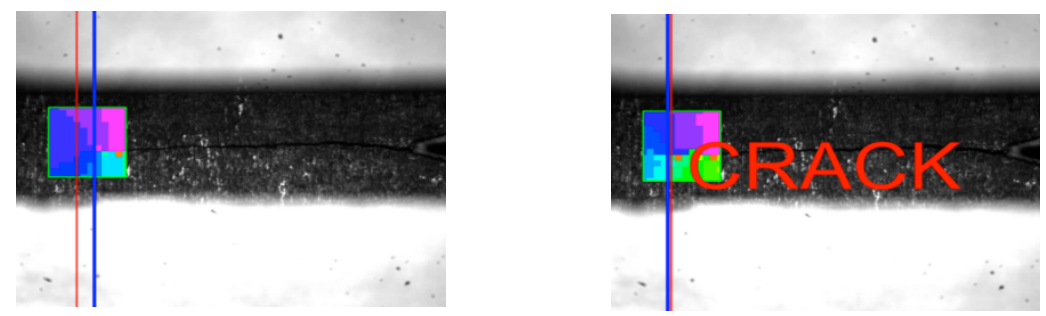

Fig. 5: Digital detection of the crack tip

Samples of the compact type which carried out the study, were stretched until the creation of the plastic hinge or to their total break. Each of them after testing was subject to measurement of the length of the initial fatigue crack. Due to the occurrence of a different state of stress and deformation at the edges and inside the material, the crack will never be equal, so it is natural to take a certain averaged value for calculations. Normative methods suggest to draw between the bottom of the mechanical notch and the end of the fatigue cracks of at least 9 lines. After averaging the length of the stretched lengths, a predetermined value of the crack length is obtained.

In the tests carried out, the length of the fatigue gap was determined differently. A photo taken on the microscope equipped with a digital camera was taken on the broken sample. The software of the mentioned camera allowed to measure the basic planimetric quantities. The surface area was measured in a digital manner and its value divided by the previously measured sample width, so as in equation:

$$
a=\frac{S_{e}}{B_{e}}
$$

where:

$S_{e}$ - empirically measured surface area of the sample

$B_{e}$ - empirically measured width of the sample

Figure 6 shows the area that the user has marked as a fatigue crack. After the calibration, an average crack length value in millimeters was calculated from Equation 1

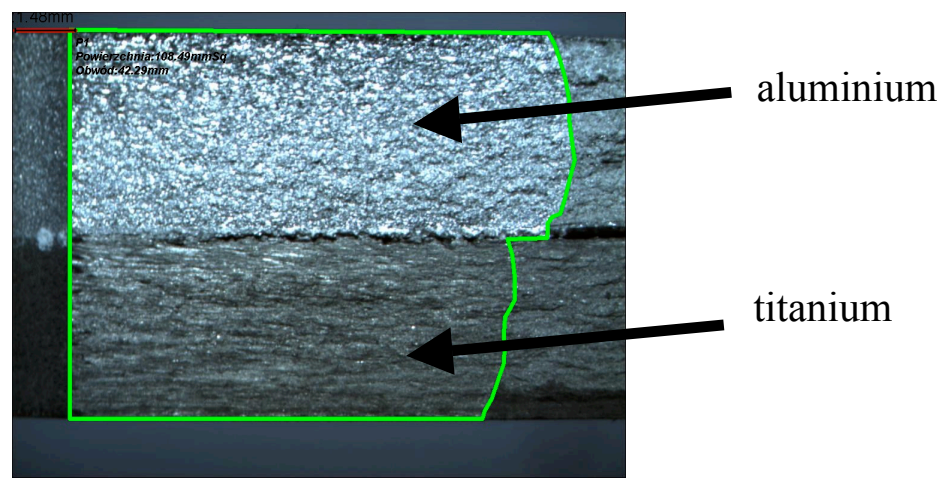

Fig. 6: Digital measurement of crack length 


\section{Results}

Fatigue crack length measurement results are summarized in Table 1. It should be noted that all dimensions are expressed in millineries. Graphical representation of the average results is shown in Figure 7. The letter B denotes thickness of the sheet, while aw is the value of the crack length used for the calculation.

Tab. 1: Results of the measurements of the length of the initial fatigue crack

\begin{tabular}{ccccccc} 
Nr & width B & aw & width Al & width Ti & precrack Al & preckrack Ti \\
\hline 3_CT_PL10_01_OC & 9.508 & 8.843 & 4.858 & 4.650 & 10.749 & 6.936 \\
\hline 3_CT_PL10_03_OC & 9.483 & 6.947 & 4.858 & 4.625 & 7.891 & 6.004 \\
\hline 3_CT_PL10_04_OC & 9.508 & 8.182 & 4.926 & 4.582 & 7.714 & 8.650 \\
\hline 3_CT_PL10_06_OC & 9.517 & 8.756 & 4.926 & 4.591 & 9.213 & 8.300 \\
\hline 3_CT_PL10_08_OC & 9.543 & 9.067 & 4.842 & 4.701 & 9.735 & 8.400 \\
\hline 3_CT_PL10_09_OC & 9.497 & 8.872 & 4.758 & 4.739 & 8.994 & 8.750 \\
\hline 3_CT_PL10_12_OC & 9.533 & 8.663 & 4.800 & 4.733 & 9.465 & 7.860 \\
\hline average value & $\mathbf{9 . 5 1 3}$ & $\mathbf{8 . 4 7 6}$ & $\mathbf{4 . 8 5 3}$ & $\mathbf{4 . 6 6 0}$ & $\mathbf{9 . 1 0 8}$ & $\mathbf{7 . 8 4 3}$ \\
\hline standard variation & $\mathbf{0 . 0 2 0}$ & $\mathbf{0 . 7 2 8}$ & $\mathbf{0 . 0 6 2}$ & $\mathbf{0 . 0 6 5}$ & $\mathbf{1 . 0 5 4}$ & $\mathbf{1 . 0 1 6}$
\end{tabular}

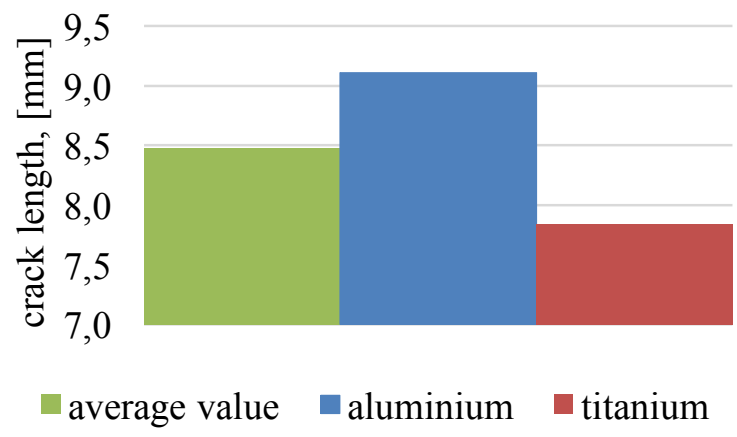

Fig. 7: Graphical representation of the average crack length measurement results

The measurement results show that during the generation of cracks in layered material is aluminum alloy damaged quickly. The average length of the fatigue crack was about than $1.2 \mathrm{~mm}$ longer than of the titanium alloy. It is interesting that just for the lightweight alloy there was a greater dispersion of results, despite the fact that the crack in the described material was crucial during the digital image correlation. The average crack length calculated on the basis of the length of cracks in the base materials is also characterized by a large spread of results.

\section{Conclusions}

Generating the initial fatigue gap in a laminar material is fraught with the risk of cracking of different lengths in each material.

The use of digital image correlation to control the fatigue crack gain gives very good results.

Based on the analysis of the obtained fatigue crack measurements, it can be assumed that the Ti6Al4V titanium alloy is more resistant to cracking than the aluminum alloy AA2519.

\section{References}

Bazarnik, P., Adamczyk-Cieślak, B., Gałka, A., Płonka, B., Snieżek, L., Cantoni, M., and Lewandowska, M. (2016). Mechanical and microstructural characteristics of Ti6A14V/AA2519 and Ti6A14V/AA1050/AA2519 laminates manufactured by explosive welding. Materials \& Design, 111, 146-157.

Melski, K. (2016). Flota przewoźników lotniczych oferujących w regionalnym ruchu regularnym na polskim rynku struktura i tendencje. Studia Oeconomica Posnaniensia, 4(7), 59-76. 